\title{
Notes
}

\section{Historical Distribution Records and New Records Confirm and Extend the Distribution of the Silver Lamprey, Ichthyomyzon unicuspis, in the Hayes River, Hudson Bay Watershed, Manitoba}

\author{
J. DAVID TySON ${ }^{1, *}$ and Douglas A. WATKINSON ${ }^{2}$ \\ ${ }^{1}$ Tetra Tech WEI Inc., 400-161 Portage Avenue East, Winnipeg, Manitoba R3B 0Y4 Canada \\ ${ }^{2}$ Freshwater Institute, Fisheries and Oceans Canada, 501 University Crescent, Winnipeg, Manitoba R3T 2N6 Canada \\ ${ }^{*}$ Corresponding author; e-mail: dave.tyson@tetratech.com
}

Tyson, J. David, and Douglas A. Watkinson. 2013. Historical distribution records and new records confirm and extend the distribution of the Silver Lamprey, Ichthyomyzon unicuspis, in the Hayes River, Hudson Bay watershed, Manitoba. Canadian Field-Naturalist 127(3): 262-265.

We reviewed historical records and observations of the Silver Lamprey (Ichthyomyzon unicuspis) in the Hayes River in the Hudson Bay watershed. New records are presented from the Seeber River in the upper Hayes River system that extend the distribution of the Silver Lamprey in northern Manitoba. A new designatable unit for the Silver Lamprey, the Southern Hudson Bay-James Bay, is proposed.

Key Words: Silver Lamprey; Ichthyomyzon unicuspis; range; distribution; Hudson Bay; Manitoba

Silver Lamprey (Ichthyomyzon unicuspis) are found in lakes and rivers from Mississippi north in the Mississippi River system into Minnesota and west in the Missouri River system into Nebraska (Page and Burr 2011). They are found throughout the Great Lakes-St. Lawrence system as far east as the St. Lawrence River in Quebec and as far west as the Lake Superior watershed in Ontario (Page and Burr 2011). Limited numbers of Silver Lamprey have been collected in Manitoba.

The abundance of Silver Lamprey in Manitoba is poorly understood, but the distribution is likely more widespread than indicated by available records (Stewart and Watkinson 2007; Committee on the Status of Endangered Wildlife in Canada (COSEWIC) 2011*). Recent distribution accounts have included the Red, Assiniboine, Winnipeg, and Nelson rivers in the Hudson Bay watershed (Stewart and Watkinson 2007; COSEWIC 2011*) (Figure 1). The Rat River was formerly included in the Manitoba distribution (Stewart and Watkinson 2007; COSEWIC 2011*), but the specimen associated with the Rat River has been re-examined by M. Docker and identified as a Chestnut Lamprey (Ichthyomyzon castaneus).

The northernmost occurrence of the Silver Lamprey is near the mouth of the Nelson River at its confluence with Seal Creek (Figure 1) (Stewart and Watkinson 2007; COSEWIC 2011*). Hubbs and Trautman (1937) reported two specimens from the Hayes River. Both specimens are deposited in the Smithsonian National Museum of Natural History at the (USNM) (museum collection acronyms follow the Registry of Biological
Repositories (http://www.biorepositories.org)). However, recent accounts of the distribution of the Silver Lamprey have not included the Hayes River (Scott and Crossman 1979; Lee et al. 1980; Stewart and Watkinson 2007; COSEWIC 2011*; Page and Burr 2011; Renaud 2011).

\section{Historical Records}

The omission of the Hayes River records (USNM 32663 and USNM 63029) from recent distribution accounts may have been due to uncertainty in the collection localities of the specimens. USNM 63029 was collected in 1900 by E. A. Preble, and the locality was recorded in the National Museum of Natural History ledger as Hill River, York Factory. The locality was later clarified as Rock Portage on the Hill River branch of the Hayes River (Hubbs and Trautman 1937). Hill River and Rock Portage do not appear in the Canadian Geographical Names Data Base (Natural Resources Canada 2013). Hill River was the former name of the Hayes River between Knee Lake and the confluence with Fox River (Figure 1) (Franklin 1823; Preble 1902). In 1901, "Hayes" was applied to the entire length of the river and all former names were suspended (Ham 1980). Preble (1902) reported that Rock Portage was 15 miles $(24.1 \mathrm{~km})$ downstream of Brassy Hill; Rock Portage generally corresponds to the location identified on the Franklin (1823) map, when corrected for errors in longitude (Figure 1) (Houston 1994). Although Rock Portage was a navigational obstruction and the site of an important Hudson's Bay Company transhipment depot 


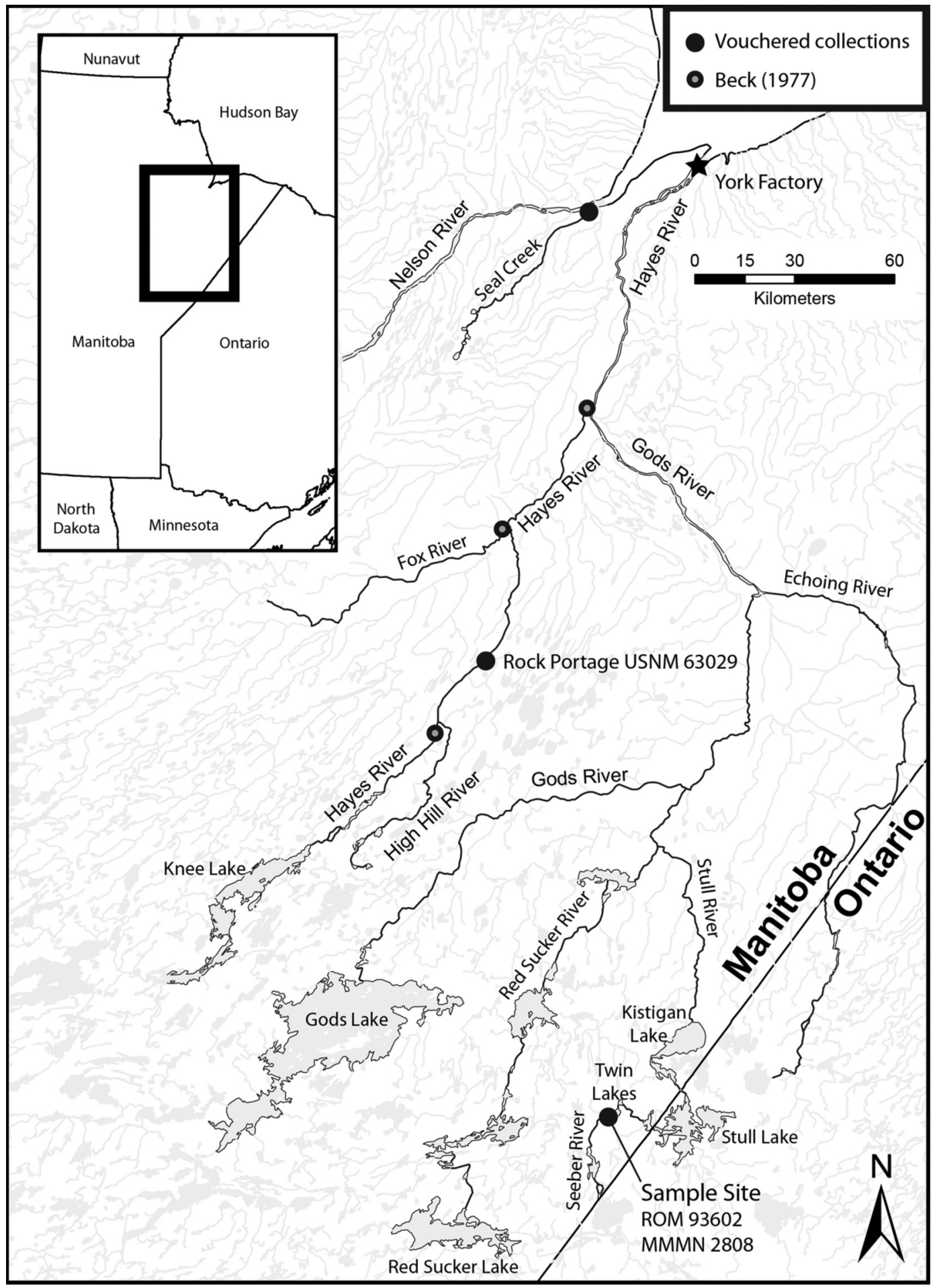

FIGURE 1. Locations of vouchered specimens and reported observations of Silver Lamprey, Ichthyomyzon unicuspis, in the Hayes River system, northeastern Manitoba. 
(Rock Depot) (Voorhis 1930), there is no contemporary name for the feature (Natural Resources Canada 2013).

Specimen USNM 32663 was received by the National Museum of Natural History in 1883 from R. Bell, and the locality information was recorded as York Factory (Figure 1). No collection date was recorded. Although York Factory is situated on the west bank of the estuary of the Hayes River, this does not indicate conclusively that the specimen was collected within the Hayes River watershed. Bell $(1879,1880)$ made several trips throughout the Churchill, Nelson, and Hayes watersheds prior to the deposit date but made no mention of collecting the specimen. As with USNM 63029 , it is likely that York Factory was used as a regional reference point for USNM 32663 rather than as a specific locality. When USNM 32663 and USNM 63029 were collected, York Factory was the most significant settlement in the sparsely populated District of Keewatin. The collection locality for USNM 32663 therefore remains uncertain.

\section{Collections in 2011}

USNM 63029 remained the only verifiable Silver Lamprey observation in the Hayes River system for more than a century until two adult Silver Lamprey were collected in the Seeber River, one on 6 September 2011 (Royal Ontario Museum 93602) and the second on 14 October 2011 (Manitoba Museum 2808) (Figure 1). The Seeber River is part of the Gods River system, and these specimens are the first documented and vouchered specimens from the upper Hayes River system.

The Seeber River specimens were attached to Northern Pike (Esox lucius), estimated to be 545 to $585 \mathrm{~mm}$ total length, collected by angling. The lampreys were tentatively identified in the field as Silver Lamprey, based on a single indented dorsal fin and unicuspid endolateral teeth on both sides of the oral disc. An identification key and description of lamprey from Renaud (2011) were used in the laboratory to confirm the identifications of the preserved specimens. The specimen collected in September 2011 was $112 \mathrm{~mm}$ total length, and the specimen collected in October 2011 was $125 \mathrm{~mm}$ total length. Specimen measurements were taken after preservation.

The Seeber River collection site $\left(54.43942^{\circ} \mathrm{N}\right.$, $92.95308^{\circ} \mathrm{W}$ ) is $2.8 \mathrm{~km}$ upstream of the Twin Lakes in a scour pool immediately downstream of a $40-\mathrm{m}$ wide boulder and bedrock chute. On 20 September 2011, the pool width was $90 \mathrm{~m}$ and maximum depth was $3.1 \mathrm{~m}$ over a substrate of cobble and boulders. The water velocity was approximately $0.9 \mathrm{~m} / \mathrm{second}$. Upstream of the collection site, the Seeber River contains a series of braided channel sections with runs, riffles, and rapids. Downstream of the collection site, the Seeber River channel expands into a series of two shallow flats ranging in width from 390 to $430 \mathrm{~m}$. The flats range from 0.5 to $1.5 \mathrm{~m}$ in depth with a substrate of silt, clay, organic matter, gravel, and boulders and contain dense beds of submerged and emergent macrophytes.

\section{Discussion}

The locality records likely do not represent a range extension for the Silver Lamprey; rather, the absence of vouchered records from these locations is a reflection of limited scientific sampling and cataloguing of fish specimens in this system. Beck (1977) recorded capturing Silver Lamprey at three locations within the Hayes River (at the confluence of the Hayes River and the Gods River, at the confluence of the Hayes River and the Fox River, and near the confluence of the Hayes River and the High Hill River) (Figure 1). Beck (1977) also reported observations of lamprey scars on fish as far upstream as Knee Lake. Voucher specimens were not retained by Beck (1977); therefore, the identifications cannot be independently confirmed. Beck (1977) speculated that Silver Lamprey were fairly common in the lower Hayes River.

Anglers have previously observed lampreys attached to host fish species at the Seeber River collection location, but these observations were not verified and documented until now. Prior to the collection of the voucher specimens, anglers in 2011 observed three lampreys attached to fishes, two Northern Pike and one Walleye (Sander vitreus), at the collection site. When shown the Silver Lamprey specimens referred to in this manuscript, aboriginal fishers from the community of Red Sucker Lake stated that lampreys are often observed throughout the Seeber River and Red Sucker River systems, with the exception of Red Sucker Lake.

The sample location for the Royal Ontario Museum (ROM) specimen (ROM 93602) and the Manitoba Museum (MMMN) specimen (MMMN 2808) is more than 430 river $\mathrm{km}$ upstream from USNM 63029 via the Gods, Red Sucker, and Stull rivers (Figure 1). The distribution of the Silver Lamprey likely extends throughout the Hayes River system in Manitoba and Ontario. Potential host species such as Lake Sturgeon (Acipenser fulvescens), Lake Whitefish (Coregonus clupeaformis), and Brook Trout (Salvelinus fontinalis) are known to move back and forth between the Hayes and Nelson river systems (Mandzy et al. 2007*; Lavergne et al. 2008*; Klassen 2012*). If movement between additional adjacent systems in the Hudson Bay watershed occurs, it is possible that Silver Lamprey are present in nearby systems.

The identification of the locality for USNM 63029 and the Seeber River records from 2011 have implications for Silver Lamprey conservation biology. The demarcation line between the Great Lakes-Upper St. Lawrence designatable unit (DU1) and the Saskatchewan-Nelson Rivers designatable unit (DU2) follows the divide between the Nelson and Hayes rivers (COSEWIC 2011*). This places the Hayes River system in DU1 (COSEWIC 2011*). The proximity of the 
mouths of the Nelson River and the Hayes River, the observed movements of potential host species between the rivers, and the current understanding of postglacial dispersal routes suggest a Nelson River origin for the Silver Lamprey in the Hayes River (Stewart and Lindsey 1983; Mandrak and Crossman 1992). Until more information is available, we recommend that the Silver Lamprey in the Hayes River be placed in a separate designatable unit (Southern Hudson Bay-James Bay) in order to maintain consistency with the delineation of the national freshwater biogeographical zones (COSEWIC 2013*).

\section{Acknowledgements}

The authors would like to thank Ross Quirie of Mega Precious Metals Inc. for collecting and freezing the specimens, Margaret Docker of the Department of Biological Sciences, University of Manitoba, for verifying the specimens, and Kris Murphy of the Smithsonian Institution for providing copies of museum ledgers and specimen jar labels for USNM 32663 and USNM 63029. Jason Jones and Neil Mochnacz reviewed the draft manuscript.

\section{Documents Cited (marked * in text)}

Committee on the Status of Endangered Wildlife in Canada (COSEWIC). 2011. COSEWIC assessment and status report on the Silver Lamprey, Great Lakes-Upper St. Lawrence populations and Saskatchewan-Nelson Rivers populations Ichthyomyzon unicuspis in Canada. Committee on the Status of Endangered Wildlife in Canada, Ottawa, Ontario. 55 pages.

Committee on the Status of Endangered Wildlife in Canada (COSEWIC). 2013. Guidelines for recognizing designatable units. Committee on the Status of Endangered Wildlife in Canada, Ottawa, Ontario. http://www.cosewic .gc.ca/eng/sct2/sct2_5_e.cfm. (Accessed 28 July 2013).

Klassen, C. N. 2012. Results of the 2011 Gods River Lake Sturgeon spawning and movement investigation. A draft report prepared by North/South Consultants Inc. for Manitoba Hydro, Winnipeg, Manitoba. Report No.11-02. 32 pages.

Lavergne, C., D. S. MacDonell, and P. A. Nelson. 2008. Brook Trout populations studies in the Conawapa study area, 2005 and 2006. A report prepared by North/South Consultants Inc. for Manitoba Hydro, Winnipeg, Manitoba. Report No. 5630.06-07. 165 pages.

Mandzy, K. M., D. S. MacDonell, L. Murray, and P. A. Nelson. 2007. Results of the 2005 fish community investigations focusing on Cisco and Lake Whitefish in the lower Nelson River. Conawapa Generation Project Environmental Studies Report No. 05-05. A report prepared by North/South Consultants Inc. for Manitoba Hydro, Winnipeg, Manitoba. Report No.5615.05-05. 57 pages.

\section{Literature Cited}

Beck, A. E. 1977. An inventory and assessment of the resources of the Hayes River. Manitoba Department of Mines, Resources and Environmental Management, Environmental Research and Development Report No. 77-3. Winnipeg, Manitoba. 199 pages.
Bell, R. 1879. Report on the country between Lake Winnipeg and Hudson's Bay, 1878. Geological Survey of Canada. Dawson Brothers, Montreal, Quebec. 31 pages.

Bell, R. 1880. Report on explorations on the Churchill and Nelson rivers and around God's and Island lakes, 1879. Geological Survey of Canada. Dawson Brothers, Montreal, Quebec. 72 pages.

Franklin, J. 1823. Narrative of a journey to the shores of the Polar Sea, in the years 1819, 20, 21, and 22. John Murray, London. 768 pages.

Ham, P. 1980. Place Names of Manitoba. Western Producer Prairie Books, Saskatoon, Saskatchewan. 153 pages.

Houston, C. S. 1994. To the Arctic by Canoe 1819-1821: The Journal and Paintings of Robert Hood, Midshipman with Franklin. McGill-Queen's University Press, Montreal, Quebec. 280 pages.

Hubbs, C. L., and M. B. Trautman. 1937. A revision of the lamprey genus Ichthyomyzon. Miscellaneous Publications of the Museum of Zoology, University of Michigan No. 35. University of Michigan, Ann Arbor, Michigan. 109 pages.

Lee, D. S., C. S. Gilbert, C. H. Hocutt, R. E. Jenkins, D. E. McAllister, and J. R. Stauffer. 1980. Atlas of North American freshwater fishes. North Carolina Biological Survey Publication No. 1980-12. North Carolina State Museum of Natural History, Raleigh, North Carolina. 867 pages.

Mandrak, N. E., and E. J. Crossman. 1992. Postglacial dispersal of freshwater fishes into Ontario. Canadian Journal of Zoology 70: 2247-2259.

Natural Resources Canada. 2013. Canadian Geographical Names Data Base. Natural Resources Canada, Ottawa, Ontario. http:/www.nrcan.gc.ca/earth-sciences/geographyboundary/geographical-name/search/5877. (Accessed 28 July 2013).

Page, L. M., and B. M. Burr. 2011. Field guide to freshwater fishes of North America north of Mexico. Houghton Mifflin Harcourt Publishing Company, New York, New York. 663 pages.

Preble, E. A. 1902. A biological investigation of the Hudson Bay region. North American Fauna No. 22. United States Department of Agriculture, Division of Biological Survey. Government Printing Office, Washington, D.C. 140 pages.

Renaud, C. B. 2011. Lampreys of the world. An annotated and illustrated catalogue of lamprey species known to date. FAO Species Catalogue for Fishery Purposes No. 5. Food and Agriculture Organization of the United Nations, Rome, Italy. 109 pages.

Scott, W. B., and E. J. Crossman. 1979. Freshwater Fishes of Canada. Third printing with revisions. Fisheries Research Board of Canada Bulletin 183. Ottawa, Ontario. 966 pages.

Stewart, K. W., and C. C. Lindsey. 1983. Postglacial dispersal of lower vertebrates in the Lake Agassiz region. Geological Association of Canada Special Paper 26: 391-419.

Stewart, K. W., and D. A. Watkinson. 2007. The freshwater fishes of Manitoba. Second printing with revisions. University of Manitoba Press, Winnipeg, Manitoba. 278 pages.

Voorhis, E. 1930. Historic forts and trading posts of the French regime and of the English fur trading companies. Department of the Interior, National Development Bureau, Ottawa, Ontario. 188 pages.

Received 8 February 2013

Accepted 18 March 2013 